\title{
Formulasi dan Uji Stabilitas Mekanik Hand and Body Lotion Sari Buah Tomat (Licopersicon esculentum Mill.) sebagai Antioksidan \\ Formulation and Mechanical Stability Test for Hand and Body Lotionfrom Tomato Juice (Licopersiconesculentum Mill.) as Antioxidants
}

\author{
Anasthasia Pujiastuti ${ }^{1 *}$, Monica Kristiani ${ }^{1}$ \\ ${ }^{1}$ Prodi D3 Farmasi, Politeknik Katolik Mangunwijaya, Semarang, Indonesia \\ email : thasia_anas@yahoo.com
}

\begin{abstract}
Abstrak
Antioksidan terkandung dalam berbagai jenis buah dan sayuran antara lain tomat (Lycopersicum esculentum Mill). Tomat memiliki kandungan likopen, flavonoid dan vitamin C sebagai antioksidan. Tomat dapat dibuat menjadi sari buah dengan menggunakan metode pengepresan. Sari buah tomat dapat dibuat sediaan farmasi dalam bentuk hand and body lotion (H\&B lotion). Tujuan penelitian ini yaitu untuk mengetahui pengaruh variasi konsentrasi sari buah tomat terhadap stabilitas fisik dan aktivitas antioksidan H\&B lotion.

Variabel bebas dalam penelitian ini adalah sari buah tomat sebagai zat aktif dengan konsentrasi $20 \%, 35 \%$, dan $50 \%$. Variabel terikatnyaadalah karakteristik fisik lotion sari buah tomatmeliputi organoleptis, $\mathrm{pH}$, viskositas, tipe emulsi, stabilitas mekanik dan aktivitas antioksidansediaan. Data yang diperoleh dari hasil penelitian dibandingkan dengan literatur dan dilakukan analisis statistik dengan taraf kepercayaan 95\%.

Hasil penelitian menunjukkan konsentrasi sari buah tomat tidak berpengaruh pada karakteristik fisik sediaan H\&B lotion dengan nilai signifikansi $>0,05$. Hasil uji stabilitas mekanik semua formula menunjukkan terjadinya peristiwa creaming. H\&B lotion sari buah tomat mempunyai aktivitas antioksidan dengan nilai IC 50 pada formula I sebesar $5,697 \mu \mathrm{g} / \mathrm{mL}$, formula II sebesar6,530 $\mu \mathrm{g} / \mathrm{mL}$, dan formula III sebesar $5,106 \mu \mathrm{g} / \mathrm{mL}$ dengan nilai signifikansi $0,00<0,05$. Hal ini berarti konsentrasi sari buah tomat berpengaruh pada aktivitas antioksidan.
\end{abstract}

Kata kunci :formulasi, lotion, tomat, stabilitas mekanik

\begin{abstract}
Antioxidants is contained in various types of fruit and vegetables included tomatoes (Lycopersicum esculentum Mill). Tomatoes have lycopene, flavonoids and vitamin $\mathrm{C}$ as antioxidants. Tomatoes can be made into fruit juice using the pressing method. Tomatoes extract can be made as pharmaceutical preparations in hand and body lotion form (H\&B lotion). The purpose of this study was to determine the effect of variations in tomato juice concentration on physical stability and antioxidant activity of $\mathrm{H} \& \mathrm{~B}$ lotion.

The independent variable in this study is the tomatoes extract concentration as of $20 \%$, $35 \%$, and $50 \%$ active ingredients. The dependent variables of this study are the physical characteristics of tomatoes extract lotion included organoleptic, $\mathrm{pH}$, viscosity, emulsion type, mechanical stability of lotion preparation and antioxidant activity of tomatoes extract lotion. The data is obtained from the results of the study compared to the relevant literature and statistical analyzes carried out with a $95 \%$ confidence level.

The results of the research showed the tomatoes extract concentration had no effect on the physical characteristics of H\&B lotion with $>0,05$ significance value. The mechanical stability test results of all formulas indicate the occurrence of creaming. $\mathrm{H} \& \mathrm{~B}$ tomatoes extract lotion has antioxidant activity with IC50 value in formula I of $5,697 \mu \mathrm{g} / \mathrm{mL}$, formula II is $6,530 \mu \mathrm{g} / \mathrm{mL}$, and formula III is $5,106 \mu \mathrm{g} / \mathrm{mL}$ with $0,00<0,05$ significance value. Means the tomatoes extract concentration influenced the antioxidants activity.
\end{abstract}

Key Words: formulations, lotion, tomato, mechanical stability 


\section{PENDAHULUAN}

Antioksidan merupakan suatu senyawa yang dapat menetralisir radikal bebas dengan cara menyumbangkan elektronnya pada senyawa radikal bebas. Senyawa antioksidan dapat mencegah kerusakan yang ditimbulkan oleh radikal bebas terhadap sel normal, protein dan lemak (Kumalaningsih, 2007 dalam Winata, 2011). Antioksidan terkandung dalam berbagai jenis makanan, terutama buah dan sayuran. Salah satu buah yang banyak mengandung antioksidan adalah tomat (Lycopersicum esculentum Mill). Kandungan utama dalam buah tomat yaitu likopen merupakan senyawa antioksidan yang sangat tinggi. Tomat juga mengandung flavonoid, vitamin $\mathrm{C}$ dan vitamin $E$ sebagai antioksidan. Antioksidan yang terkandung dalam buah tomat mampu melawan radikal bebas akibat polusi dan radiasi sinar UV (Imam, 2006). Menurut Maulida dan Zulkarnaen(2010) likopen mempunyai kemampuan dalam mengendalikan radikal bebas 100 kali lebih efisien dibandingkan vitamin E dan 12500 kali dari pada gluthation.

Kandungan likopen dalam 100 gram buah tomat mentah rata-rata mencapai 3-5 gram (Tsang, 2004). Berdasarkan penelitian Swastika (2013) diketahui bahwa pada konsentrasi $20 \%$ sari buah tomat dapat berperan sebagai antioksidan. Sari buah tomat dapat dibuat menjadi suatu sediaan kosmetika yang berkhasiat sebagai antioksidan topikal.

Sediaan kosmetika topikal yang dapat dengan mudah diaplikasikan pada seluruh tubuh antara lain hand and body lotion ( $\mathrm{H} \& \mathrm{~B}$ lotion). $\mathrm{H} \& \mathrm{~B}$ lotion merupakan sediaan emulsi yang diaplikasikan secara topikal. Emulsi yang digunakan pada kulit dapat berupa minyak dalam air (M/A) atau air dalam minyak (M/A) (Allen, dkk., 2014). Konsistensi sediaan lotion berbentuk cair sehingga memungkinkan pemakaian yang cepat dan merata pada permukaan kulit jika dibandingkan dengan sediaan krim atau salep.

Komponen dasar sediaan lotion yaitu fase internal, fase eksternal dan emulgator. Emulgator berfungsi sebagai bahan pengemulsi untuk menstabilkan sediaan emulsi (Allen, dkk., 2014). Stabilitas suatu sediaan dapat diketahui dari serangkaian pengujian fisik untuk mengetahui karakteristik H\&B lotion dan uji stabilitas sediaan. Salah satu metode uji stabilitas yang dapat digunakan adalah uji stabilitas mekanik menggunakan metode sentrifugasi dengan kecepatan tinggi.

Berdasarkan latar belakang tersebut maka perlu dilakukan penelitian tentang formulasi sediaan H\&B lotion sari buahtomat yang memiliki aktivitas antiokasidan. Pada penelitian ini bertujuan untukmengetahui pengaruh variasi konsentrasi sari buah tomat terhadap stabilitas fisik dan aktivitas antioksidan H\&B lotion. Penelitian ini diharapkan dapat meningkatkan pemanfaatan tomat (Lycopersicum esculentum Mill) menjadi sediaan H\&B lotion antioksidan.

\section{METODE PENELITIAN} Alat dan Bahan

Alat yang digunakan dalam penelitian ini adalahneraca analitik, gelas ukur, beaker glass, cawan porselin, mortir stamper, pengaduk 
gelas, botol $200 \mathrm{~mL}$, tabung reaksi, object glass, stopwatch, alat uji daya sebar, alat uji daya lekat, viskometer DV-E Brookfield, penangas air, kertas saring, mikroskop Olympus, blender, pisau, $\mathrm{pH}$ universal, sentrifugator dan SpektrofotometerUV-VIS.

Bahan yangdigunakan dalam penelitian ini yaitu buah tomat, tween 80, paraffin liquidum, aquadest, setil alkohol, propilenglikol, natrium benzoate, asam stearate, indikator phenolphtalein, paraffin padat, dan kalium hidroksida $0,1 \mathrm{~N}$.

\section{Pembuatan Sari Buah Tomat}

Sari buah tomat merupakan cairanyang jernih atau hampir jernih yang tidakmengalami proses fermentasi, diperolehdengan cara pengepresan ataupenghancuranbuah tomat yang telah masak dan segar. Tomat yang digunakan diperoleh dari pasar Prembaen,Semarang. Pembuatan sari buah tomat diawali dengan mencuci buah tomat, diiris dan dipotong kecil-kecil, lalu dimasukkandalam blender tanpa penambahan air, kemudian disaring untuk memisahkan filtrat dan residunya. Sari buah tomat berupa cairan yang telah dipisahkan dari residunya.

\section{Formula H \& B Lotion Sari Buah Tomat}

Hand \& Bodylotion sari buah tomat dibuat 3 formula dengan 3 variasi konsentrasi yaitu 20, 35 dan 50\%. Setiap formula H\&B lotion dibuat sebanyak 150 gram. Formula H\&B Iotion sari buah tomat dapat dilihat pada Tabel I.

\section{Pembuatan H\&B Lotion Sari Buah Tomat}

Pembuatan sediaan H\&B lotion sari buah tomat diawali dengan penentuan fase air dan fase minyak. Fase minyak terdiri dari setil alkohol, asam stearat dan paraffin liquidum. Fase air terdiri dari sari buah tomat, tween 80, propilenglikol, natrium benzoate dan aquadest. Natrium benzoate dilarutkan dalam aquadest panas sebanyak $10 \mathrm{~mL}$ hingga larut, kemudian dicampurkan dengan sari buah tomat, propilen glikol dan tween 80 hingga homogen diatas penangas air sampai suhu $70^{\circ} \mathrm{C}$.

Tabel I. Formula H \& B Iotion sari buah tomat

\begin{tabular}{lccc}
\hline \multirow{2}{*}{ Nama Bahan } & \multicolumn{3}{c}{ Jumlah Bahan (\%) } \\
\cline { 2 - 4 } & F I & F II & F III \\
Sari buah tomat & 20 & 35 & 50 \\
Propilen glikol & 15 & 15 & 15 \\
\hline Tween 80 & 10 & 10 & 10 \\
\hline Paraffin liquidum & 10 & 10 & 10 \\
Setil alkohol & 8 & 8 & 8 \\
Asam stearat & 6 & 6 & 6 \\
\hline Natrium benzoate & 0,3 & 0,3 & 0,3 \\
\hline Aquadest sampai & 100 & 100 & 100 \\
\hline
\end{tabular}


Asam stearat dilelehkan diatas penangas air pada suhu $70^{\circ} \mathrm{C}$ hingga meleleh sempurna, kemudian dimasukkan setil alkohol dan paraffin liquidum selanjutnya diaduk hingga homogen. Fase minyak dicampur menjadi satu dengan fase air dalam cawan pada suhu $70^{\circ} \mathrm{C}$ sambil diaduk dan dicukupkan hingga menghasilkan sediaan H \& B lotionsebanyak 150 gram. Sediaan H \& B lotion didinginkan sambil dilakukan pengadukan hingga suhu kamar. Pengadukan dilakukan sampai terbentuk massa yang kental dan homogen.

\section{Pengujian Karakteristik Fisik Sediaan H\&B Lotion \\ a) Organoleptis}

Pengujian

organoleptis

dilakukan dengan mengamati sediaan $\mathrm{H} \& \mathrm{~B}$ lotion sari buah tomat yang meliputi warna, bau, dan rasa H\&B lotion ketika dioleskan di kulit (Sulaiman \& Kuswahyuning,2008).

\section{b) Homogenitas}

Pengujian

homogenitas

dilakukan dengan cara menimbang sebanyak $0,1 \mathrm{~g} \mathrm{H} \& \mathrm{~B}$ lotion sari buah tomat. H\&B lotion diletakkan di tengah object glass lalu diratakan dan ditutup dengan object glass lainnya. Homogenitas lotion diamati menggunakan kaca pembesar, dan diperhatikan ada tidaknya partikelpartikel kasar atau ketidakhomogenan pada sediaan.

c) $\mathrm{pH}$

Pengujian $\mathrm{pH}$ sediaan $\mathrm{H} \& \mathrm{~B}$ lotion sari buah tomat dilakuan menggunakan $\mathrm{pH}$ universal. Sediaan $\mathrm{H} \& \mathrm{~B}$ lotion dioleskan pada kertas $\mathrm{pH}$ universal dan dilakukan pengamatan terjadinya perubahan warna pada kerta $\mathrm{pH}$. Warna yang muncul pada kertas $\mathrm{pH}$ universal selanjutnya dicocokan dengan warna pada indikator $\mathrm{pH}$ yang terdapat pada kemasan $\mathrm{pH}$ universal.

\section{d) Viskositas}

Pengujian viskositas sediaan $\mathrm{H}$ \& B lotion sari buah tomat akan dilakukan dengan memasukkan 120 gram sediaan ke dalam wadah, kemudian diukur viskositasnya menggunakan viskometer Brookfield tipe DV-E. Pengukuran dimulai dengan melakukan pemasangan spindle nomor 64 dengan memutar pengunci spindle searah jarum jam. Kecepatan spindle diatur pada kecepatan $10 \mathrm{rpm}$. Pengukuran viskositas dicatat dari angka yang paling lama dan sering muncul pada layar viscometer dengan persentase kurang lebih $58 \%$.

\section{e) Daya Lekat}

$\mathrm{H} \& \mathrm{~B}$ lotion sari buah tomat ditimbang sebanyak $0,1 \mathrm{~g}$ diletakkan di tengah object glass dan ditutup dengan object glass lainnya. Anak timbangan 50 $\mathrm{g}$ diletakkan di atas object glass penutup selama 5 menit. Ujung object glass penutup dan ujung object glass bagian bawah dikaitkan dengan penjepit pada alat uji daya lekat, lalu penyangga beban dilepas. Lama waktu kedua object glass terlepas dari alat uji dicatat sebagai waktu lekat sediaan.

\section{f) Daya Sebar}

Pengujian daya sebar dilakukan dengan menimbang sediaan $\mathrm{H} \& \mathrm{~B}$ lotion sari buah tomat sebanyak $0,5 \mathrm{~g}$ diletakkan di tengah kaca bundar berskala, diatas sediaan diletakkan kaca bundar lain yang telah ditimbang lalu didiamkan selama 1 menit dan dicatat 
diameter penyebarannya. Beban seberat $50 \mathrm{~g}$ ditambahkan diatas kaca penutup dan didiamkan selama 1 menit lalu dicatat diameter penyebarannya. Pemberat ditambahkan dengan kelipatan $50 \mathrm{~g}$ hingga mencapai $200 \mathrm{~g}$, kemudian diukur diameter dan luas penyebarannya.

\section{g) Daya Proteksi}

Pengujian daya proteksi dilakukan dengan cara membasahi kertas saring berdiameter $10 \mathrm{~cm}$ dengan indikator phenolphthalein (PP), kemudian dikeringkan. Sediaan H\&B lotion sari buah tomat sebanyak $0,5 \mathrm{~g}$ dioleskan pada kertas saring secara merata pada seluruh permukaan kertas saring. Kertas saring tersebut ditutup dengan kertas saring lain dengan ukuran 2,5 x 2,5 cm yang diberi pembatas paraffin padat yang sudah dicairkan, kemudian ditetesi area dengan 1 tetes $\mathrm{KOH} \mathrm{0,1N}$. Dicatat waktu hingga terjadi perubahan warna pada kertas saring. Hasil uji kemampuan proteksi ditunjukkan dengan munculnya noda berwarna merah muda pada kertas saring.

\section{h) Tipe Emulsi}

Pengujian tipe emulsi yang akan digunakan adalah metode pewarnaan. Pengujian ini akan dilakukan dengan mengambil sedikit $\mathrm{H}$ \& $\mathrm{B}$ lotion sari buah tomat dan diletakkan pada object glass, kemudian ditambahkan 1 tetes metilen blue, dicampurkan hingga homogen dan diamati menggunakan mikroskop. Apabila fase eksternal terwarnai biru, maka sediaan bertipe minyak dalam air (M/A) (Voigt, 1995).

\section{Pengujian Stabilitas Hand \& BodyLotion}

Pengujian stabilitas H\&B lotion sari buah tomat dilakukan dengan metode uji mekanik. Metode ini dilakukan dengan cara sebanyak $14 \mathrm{~mL}$ $\mathrm{H} \& \mathrm{~B}$ lotion dimasukkan ke dalam tabung sentrifugasi. Tabung sentrifugasi dimasukkan ke dalam alat sentrifugator pada kecepatan 3600 rpm selama 4,5 jam, kemudian sediaan diamati perubahan fisik yang ditandai dengan pemisahan fase emulsi. Pengujian stabilitas H\&B lotion sari buah tomat dilakukan berdasarkan modifikasi dari penelitian Setiawati dkk., 2014 yang disesuaikan dengan tipe sentrifugator yang digunakan.

\section{Uji Aktivitas Antioksidan}

Uji Aktivitas antioksidan pada penelitian ini ditentukan dengan metode diphenyl picryl hidrazy/(DPPH) dengan cara H\&B lotion sari buat tomat dilarutkan dalam air $10 \mathrm{~mL}$, larutan diambil sebanyak $1 \mathrm{~mL}$ dan ditambahkan dengan 4,0 mL DPPH. Campuran selanjutnya dihomogenkan dan dibiarkan selama 30 menit. Langkah selanjutnya yaitu mengukur absorbansinya pada panjang gelombang $517 \mathrm{~nm}$ dan dilakukan pengukuran blanko. Hasil penetapan antiradikal dibandingkan dengan vitamin C. Nilai serapan larutan DPPH dihitung sebagai persen inhibisi (\% inhibisi) dihitung dengan rumus (Zuhra, dkk, 2008) :

$\% \mathrm{I}=\frac{(\text { Abs blangko-Abs sample })}{\text { Abs blangko }} \times 100 \%$ 
HASIL DAN PEMBAHASAN

1. Organoleptis Sediaan Hand \& Body Lotion Sari Buah Tomat

Pengamatan organoleptis sediaan $\mathrm{H} \& \mathrm{~B}$ lotion sari buah tomat dilakukan secara visual untuk mengetahui bentuk, warna, bau, dan rasa sediaan ketika dioleskan pada kulit. Hasil pengamatan organoleptis $\mathrm{H} \& \mathrm{~B}$ lotion sari buah tomatberbentuk setengah padat, berwarna jingga, dan tidak berbau. Pada saat diaplikasikan di kulit terasa lembut. Pada semua formula menghasilkan organoleptis yang sama, hal ini dikarenakan ketiga formula menggunakan komponen bahan dan cara pembuatan yang sama. Warna jingga pada semua formula dihasilkan dari warna sari buah tomat. Intensitas warna jingga yang dihasilkan dari ketiga formula sedikit berbeda. Pada formula I warna jingga yang dihasilkan lebih muda dibandingkan warna formula II dan III. Pada formula III intensitas warna jingga yang dihasilkan lebih pekat dari formula I dan II. Perbedaan intensitas warna jingga yang dihasilkan dari ketiga formula dipengaruhi oleh variasi konsentrasi sari buah tomat yang digunakan dalam tiap formula, semakin tinggi konsentrasi sari buah tomat yang digunakan semakin pekat warna jingga yang dihasilkan. Sediaan H\&B lotion sari buah tomat dari ketiga formula dapat dilihat pada Gambar 1.

\section{Homogenitas Hand \& Body Lotion} Sari Buah Tomat

Pengujian homogenitas
dilakukan untuk mengetahui
tercampurnya bahan-bahan sediaan
lotion. Homogenitas suatu sediaan
dipengaruhi oleh proses pencampuran
pada saat pembuatan sediaan.

Berdasarkan hasil penelitian diketahui bahwa peningkatan konsentrasi sari buah tomat tidak mempengaruhi homogenitas sediaan $\mathrm{H} \& \mathrm{~B}$ lotion sari buah tomat, karena semua komponen bahan tercampur secara homogen.

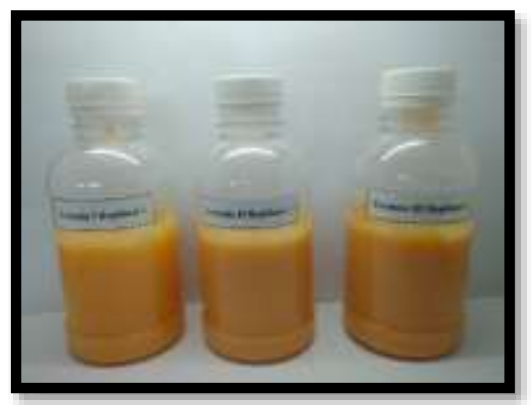

\section{Gambar 1. Sediaan H\&B Lotion Sari Buah Tomat}

\section{3. pH Hand \& Body Lotion Sari Buah Tomat}

Pengukuran $\mathrm{pH}$ bertujuan untuk mengetahui derajat keasaman atau kebasaan yang dimiliki oleh suatu sediaan yang dapat mempengaruhi kenyamanan pada saat diaplikasikan. Hasil pengujian $\mathrm{pH}$ sediaan H\&B lotion sari buah tomat pada semua formula menunjukkan $\mathrm{pH}$ yang sama yaitu 5 . Berdasarkan nilai $\mathrm{pH}$ semua formula memenuhi persyaratan $\mathrm{pH}$ sediaan pelembab kulityaitu 4,5 - 8 (SNI, 1996). Lotion yang memiliki $\mathrm{pH}$ terlalu basa dapat menyebabkan kulit menjadi kering, sedangkan jika $\mathrm{pH}$ terlalu asam akan menimbulkan iritasi (Barel,dkk., 2001).

\section{Viskositas Hand \& Body Lotion Sari Buah Tomat}

Uji viskositas dilakukan untuk mengetahui kekentalan suatu sediaan. Pengujian viskositas pada penelitian ini menggunakan viskometer Brookfield tipe DV-E. Hasil pengujian viskositas 
dapat dilihat pada Tabel II.Viskositas yang dihasilkan dari semua formula memenuhi syarat viskositas sediaan pelembab kulit yaitu 2000-50000 cP (SNI, 1996). Nilai viskositas yang dihasilkan selanjutnya dilakukan analisis statistik yang menunjukkan bahwa data viskositas dari semua formula yang diperoleh terdistribusi normal, pada formula I nilai signifikasinya $0,780(p>0,05)$, formula II nilai signifikasinya $0,463(p>0,05)$ dan formula III nilai signifikasinya 1,000 $(p>0,05)$. Data viskositas juga terdistribusi secara homogen dengan nilai signifikasi $0,369(p>0,05)$. Data viskositas yang terdistribusi normal dan homogen selanjutnya dilakukan uji Anova. Berdasarkan uji Anova, viskositas sediaan $\mathrm{H} \& \mathrm{~B}$ lotion sari buah tomat dengan perbedaan konsentrasi sari buah tomat menunjukkan adanya perbedaan yang tidak bermakna ( $\mathrm{p}=$ $0,086>0,05)$. Hal ini berarti konsentrasi sari buah tomat tidak mempengaruhi viskositas sediaan $\mathrm{H} \& \mathrm{~B}$ lotion sari buah tomat.

\section{Daya Lekat Hand \& Body Lotion Sari Buah Tomat}

Pengujian daya lekat dilakukan untuk mengetahui lamanya lotion melekat ketika diaplikasikan pada kulit. Hasil pengujian daya lekat sediaan $\mathrm{H}$ \& B lotion sari buah tomat dapat dilihat pada Tabel II. Berdasarkan hasil penelitian diketahui bahwa semakin besar konsentrasi sari buah tomat menghasilkan kemampuan daya lekat yang semakin kecil. Hal ini dipengaruhi oleh konsistensi sari buah tomat berupa cairan encer menyerupai aquadest sehingga jumlah aquadest yang ditambahkan dalam setiap formula semakin sedikit. Pada formula dengan konsentrasi sari buah tomat yang semakin besar menggunakan jumlah aquadest yang semakin sedikit. Konsentrasi sari buah tomat mempengaruhi daya lekat dari sediaan $\mathrm{H} \& \mathrm{~B}$ lotion sari buah tomat, semakin besar konsentrasi sari buah tomat yang digunakan menunjukkan penurunan daya lekat dari sediaan H\&B lotion sari buah tomat.Daya lekat yang baik akan menghasilkan waktu kontak dengan kulit yang lebih lama, sehingga dapat memberikan efek yang maksimal.

$$
\text { Hasil analisis statistik }
$$

menunjukkan bahwa daya lekat semua formula terdistribusi normal. Pada formula I menghasilkan nilai signifikasi $0,307$ ( $p>0,05)$, formula II nilai signifikasi $1,000(p>0,05)$ dan formula III nilai signifikasinya 0,463 ( $p>0,05$ ). Data daya lekat dari ketiga formula terdistribusi tidak homogen dengan nilai signifikasi 0,014 $(p<0,05)$. Hasil analisis statistik daya lekat sediaan H\&B lotion sari buah tomat menunjukkan data terdistribusi secara normal dan varian berbeda (tidak homogen)

\section{Tabel II. Viskositas dan Daya Lekat H\&B Lotion Sari Buah Tomat}

\begin{tabular}{ccc} 
Formula & $\begin{array}{c}\text { Rerata Viskositas (cP) } \\
\mathbf{\mathbf { S D }}\end{array}$ & $\begin{array}{c}\text { Rerata Daya Lekat (detik) } \\
\mathbf{\text { SD }}\end{array}$ \\
\hline I & $35120 \pm 151$ & $1,41 \pm 0,19$ \\
\hline II & $34880 \pm 125$ & $1,02 \pm 0,01$ \\
\hline III & $35100 \pm 60$ & $0,92 \pm 0,04$ \\
\hline
\end{tabular}


sehingga dilanjutkan dengan uji one way anova dengan post hoc Games Howell. Berdasarkan uji one way anova, daya lekat sediaan H\&B lotion sari buah tomat dengan perbedaan konsentrasi sari buah tomat menunjukkan adanya perbedaan yang bermakna $(p=0,004<$ $0,05)$.Analisis statistik selanjutnya dengan post hoc Games Howell yang didapatkan hasil bahwa antara formula I dan II $(p=0,121>0,05)$ berbeda tidak bermakna, formula I dan III ( $p=0,073>$ 0,05 ) berbeda tidak bermakna, formula II dan III $(p=0,092>0,05)$ berbeda tidak bermakna. Berdasarkan analisis statistik konsentrasi sari buah tomat tidak berpengaruh pada daya lekat H\&B lotion sari buah tomat.Hal ini berarti perbedaan hasil pengujian daya lekat $\mathrm{H} \& \mathrm{~B}$ lotion pada tiap formula berbeda tetapi tidak bermakna.

\section{Daya Sebar Hand \& Body Lotion Sari Buah Tomat}

Pengujian daya sebar dilakukan untuk mengetahui kemampuan menyebar sediaan saat diaplikasikan pada kulit. Sedian yang baik adalah sediaan yang mudah menyebar pada kulit, tanpa menggunakan tekanan yang besar.

Hasil penelitian menyatakan bahwa penambahan beban menghasilkan diameter penyebaran yang semakin besar, sehingga semakin luas juga persebarannya. Luas penyebaran dapat menunjukkan kemudahan dalam mengaplikasikan sediaan pada kulit. Hasil analisis statistik menunjukkan bahwa data diameter persebaran semua formula yang diperoleh terdistribusi normal, pada formula I nilai signifikasinya 0,069 $(p>0,05)$, formula II nilai signifikasinya
$0,892$ ( $p>0,05)$ dan formula III nilai signifikasinya $0,906(p>0,05)$. Data diameter persebaran dari ketiga formula terdistribusi secara homogen dengan nilai signifikasinya $0,218(p>0,05)$. Hasil analisis statistik daya sebar sediaan $\mathrm{H}$ \& $\mathrm{B}$ lotion sari buah tomat menunjukkan data terdistribusi secara normal dan homogen, sehingga dilanjutkan dengan uji Anova. Berdasarkan uji Anova, diameter persebaran sediaan H\&B lotion sari buah tomat dengan perbedaan konsentrasi sari buah tomat menunjukkan adanya perbedaan yang tidak bermakna $(p=0,098>0,05)$. Hal ini berarti konsentrasi sari buah tomat tidak mempengaruhi diameter persebaran sediaan H\&B lotion sari buah tomat.

\section{Daya Proteksi Sediaan Hand \&} Body Lotion Sari Buah Tomat

Pengujiandaya

proteksi dilakukan untuk mengetahui kemampuan proteksi atau perlindungan terhadap pengaruh asing dari luar yang dapat mengurangi efektivitas dari H\&B lotion.Pengujian daya proteksi menggunakan phenolphthalein (PP) dan $\mathrm{KOH} \mathrm{0,1} \mathrm{N} \mathrm{sebagai} \mathrm{indikator.} \mathrm{Data}$ hasil penelitian pada semua formula memiliki daya proteksi yang baik. Perbedaan konsentrasi sari buah tomat tidak berpengaruh pada daya proteksi dari H\&B lotion yang dibuat. Hal ini ditunjukkan dengan tidak timbul warna merah pada semua kertas saring dari ketiga formula. Hasil tersebut menyatakan bahwa sediaan H\&B lotion sari buah tomat mampu memproteksi dengan baik sehingga dapat menghalangi terjadinya reaksi antara kalium hidroksida dengan phenolptalein 
yang ditunjukkan dengan tidak timbulnya warna merah.

\section{Tipe Emulsi}

Pengujian tipe emulsi H\&B lotion sari buah tomat bertujuan untuk mengetahui $\mathrm{H} \& \mathrm{~B}$ lotion yang dihasilkan mempunyai tipe minyak dalam air (M/A) atau air dalam minyak (A/M). Pengujian dilakukan dengan metode pewarnaan menggunakan indikator warna methylen blue. Pengujian formula I, II, dan III memberikan hasil yang sama yaitu termasuk dalam tipe emulsi minyak dalam air (M/A). Hasil pengujian tipe emulsi dapat dilihat pada Gambar 2.

Hasil yang diperoleh adalah fase air sebagai fase eksternal terwarnai oleh methylen blue, sedangkan fase minyak sebagai fase internal tidak terwarnai oleh methylen blue. Kelarutan dari methylen blue yaitu larut dalam air sehingga dapat memberikan warna biru pada fase air. Peningkatan konsentrasi sari buah tomat tidak memberikan pengaruh pada tipe emulsi sediaan $\mathrm{H} \& \mathrm{~B}$ lotion sari buah tomat.

\section{Stabilitas Emulsi Sediaan Hand \& Body Lotion}

Pengujian stabilitas emulsi dilakukan untuk mengetahui kestabilan H\&B lotion sari buah tomat setelah pengocokan dengan kecepatan tinggi. Pengujian stabilitas emulsi dalam penelitian ini menggunakan metode uji mekanik dengan alat sentrifugator. Uji sentrifugasi merupakan salah satu indikator kestabilan fisik sediaan semipadat. H\&B lotion setelah dilakukan sentrifugasi dapat dilihat pada Gambar 3.

Hasil sentrifugasi yang dilakukan pada semua formula H\&B lotion sari buah tomat mengalami pemisahan, tetapi bukan pemisahan antara fase minyak dan air. Pemisahan ditandai dengan timbulnya perbedaan warna pada bagian dasar sediaan pada tabung sentrifugasi, kondisi demikian disebut creaming.

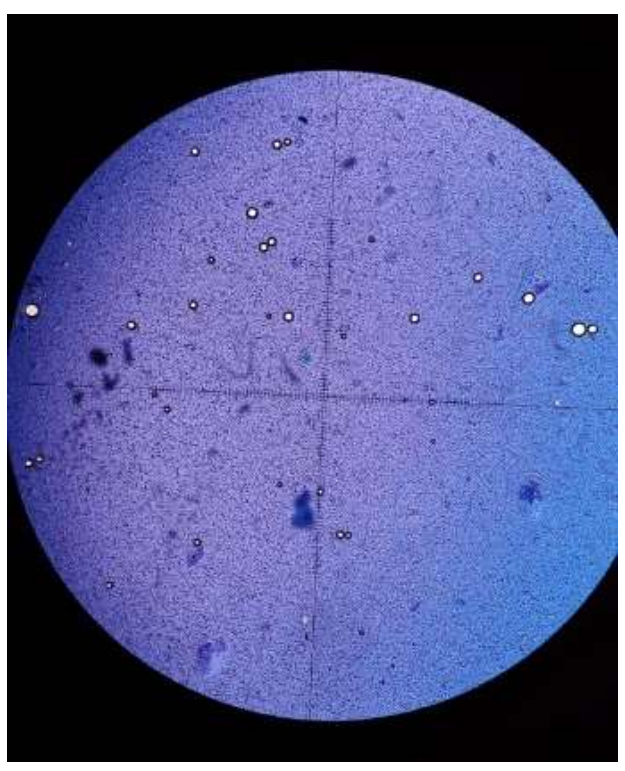

Gambar 2. Hasil Pengujian Mikroskopik Tipe Emulsi H\&B Lotion Sari Buah Tomat 


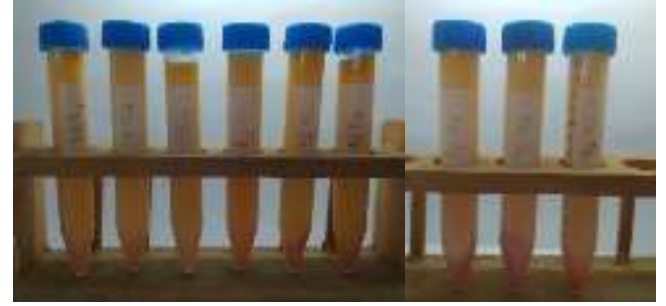

Gambar 3.Hasil Pengujian Stabilitas Emulsi H\&B Lotion Sari Buah Tomat

Creaming merupakan peristiwa terbentuknya lapisan-lapisan dengan konsentrasi yang berbeda-beda pada emulsi. Hal ini terjadi karena dipengaruhi oleh gaya gravitasi, partikel yang memiliki kerapatan lebih rendah akan naik ke permukaan dan kerapatan yang lebih tinggi akan membentuk lapisan pada bagian bawah sediaan. Creaming merupakan salah satu bentuk ketidakstabilan emulsi yang bersifat reversible, yaitu sediaan dapat terdispersi kembali dengan penggojokan ringan dan dapat membentuk suatu campuran yang homogen (Ansel, 1989). Berdasarkan Gambar 3, dapat dilihat bahwa pada formula III pemisahannya terlihat semakin jelas karena konsentrasi sari buah tomat paling tinggi yaitu sebesar $50 \%$. Hal ini terjadi karena sari buah tomat dengan konsentrasi $50 \%$ memiliki kerapatan yang paling tinggi dibandingkan dengan formula I dan II.

10. Aktivitas Antioksidan Sediaan Hand \& Body Lotion

Pengujian aktivitas antioksidan sediaan $\mathrm{H} \& \mathrm{~B}$ lotion sari buah tomat dilakukan menggunakan metode DPPH (2,2difenil-1-pikril hidrazil) dengan alat sepektrofotometer UV-Vis. Aktivitas antioksidan diukur dengan menghitung jumlah pengurangan intensitas warna ungu DPPH yang sebanding dengan pengurangan konsentrasi larutan DPPH. Hal tersebut terjadi karena adanya reaksi antara molekul DPPH dengan atom hidrogen yang dilepaskan satu molekul komponen sampel sehingga terbentuk senyawa DPPH dan menyebabkan terjadinya peluruhan warna DPPH dari ungu menjadi kuning (Mu'nisa, 2012). Nilai absorbansi hasil pengujian digunakan untuk penentuan nilai persen inhibisi. Hasil persen inhibisi vitamin $\mathrm{C}$ dapat dilihat pada Tabel III.

Tabel III. Persen InhibisiVitamin C

\begin{tabular}{ccc}
\hline $\begin{array}{c}\text { Konsentrasi } \\
\text { (ppm) }\end{array}$ & Absorbansi & $\begin{array}{c}\text { Persen } \\
\text { Inhibisi }\end{array}$ \\
\hline $\mathbf{0}$ & 0,6193 & 0,000 \\
\hline $\mathbf{1 0}$ & 0,5411 & 9,847 \\
\hline $\mathbf{1 5}$ & 0,5002 & 16,661 \\
\hline $\mathbf{2 5}$ & 0,4398 & 26,724 \\
\hline $\mathbf{5 0}$ & 0,3622 & 39,653 \\
\hline $\mathbf{1 0 0}$ & 0,2194 & 63,446 \\
\hline $\mathbf{1 5 0}$ & 0,0865 & 85,588 \\
\hline
\end{tabular}

Persen inhibisi dapat digunakan untuk mengetahui aktivitas antioksidan sampel uji. Persen inhibisi yang semakin tinggi dipengaruhi oleh menurunnya nilai absorbansi yang dihasilkan sampel. Konsentrasi sampel yang semakin tinggi menghasilkan nilai absorbansi yang semakin kecil sehingga menyebabkan persen inhibisi semakin tinggi (Hardiyanthi, 2015).

Aktivitas antioksidan dari $\mathrm{H} \& \mathrm{~B}$ lotion sari buah tomat dinyatakan dalam persen inhibisinya terhadap radikal DPPH. Persen inhibisi ini didapatkan dari perbedaan serapan antara absorban DPPH dengan absorban 
sampel yang diukur dengan spektrofotometer UV-Vis.Pengukuran persen inhibisi H\&B lotion sari buah tomat dilakukan pada konsentrasi 5000 ppm.Hasil persen inhibisi dan IC50 ketiga formula H\&B lotion sari buah tomat dapat dilihat pada Tabel IV.

Tabel IV. Aktivitas Antioksidan H\&B Lotion Sari Buah Tomat

\begin{tabular}{ccc}
\hline Formula & $\begin{array}{c}\text { Persen } \\
\text { Inhibisi }\end{array}$ & $\begin{array}{c}\text { IC }_{50} \\
(\boldsymbol{\mu g} / \mathbf{m L})\end{array}$ \\
\hline I & 4,982 & 5,697 \\
\hline II & 5,440 & 6,530 \\
\hline III & 4,657 & 5,106 \\
\hline
\end{tabular}

Berdasarkan Tabel III dan Tabel IV dapat diketahui bahwa persen inhibisi vitamin $\mathrm{C}$ jauh lebih besar jika dibandingkan dengan persen inhibisiH\&B lotion sari buah tomat. Hal ini terjadi karena vitamin $\mathrm{C}$ telah terbukti memiliki aktivitas antioksidan yang tinggi dan telah banyak dimanfaatkan sebagai antioksidan dalam kehidupan seharihari.

Tabel IVmemperlihatkan bahwa formula II memiliki persen inhibisi yang lebih besar dibandingkan formula I dan III. Hasil analisis statistik menunjukkan bahwa data persen inhibisi terdistribusi normal, pada formula I nilai signifikasinya $0,520(p>0,05)$, formula II nilai signifikasinya $0,826(p>0,05)$ dan formula III nilai signifikasinya 0,780 $(p>0,05)$. Data persen inhibisi dari ketiga formula terdistribusi secara homogen dengan nilai signifikasinya $0,890$ ( $p>0,05)$. Hasil analisis statistik persen inhibisisediaan $\mathrm{H}$ \& $\mathrm{B}$ lotion sari buah tomat menunjukkan data terdistribusi secara normal dan homogen, sehingga dilanjutkan dengan uji Anova. Berdasarkan uji Anova, persen inhibisi sediaan $\mathrm{H} \& \mathrm{~B}$ lotion sari buah tomat dengan perbedaan konsentrasi sari buah tomat menunjukkan adanya perbedaan yang bermakna ( $p=0,001<0,05)$. Analisis statistik selanjutnya dengan post hoc Bonferroniuntuk mengetahui adanya perbedaan antar formula. Uji post hocdidapatkan hasil bahwa antar formula I, II dan III nilai signifikansinya yaitu $0,001<0,05$ yang berarti terdapat perbedaan yang bermakna pada tiap formula. Berdasarkan analisis statistik konsentrasi sari buah tomat berpengaruh padaberpengaruh padapersen inhibisi sediaan H\&B lotion sari buah tomat.

Nilai persen inhibisi atau persen peredaman senyawa antioksidan (sampel) terhadap DPPH tidak dapat secara langsung dipakai sebagai parameter utama aktivitas antioksidan dari suatu sampel. Hal ini karena persen inhibisi merupakan respon dari tiap konsentrasi uji sehingga tidak menggambarkan aktivitas antioksidan yang paling baik di antara semua sampel yang diujikan (Molyneux, 2004, dalamHardiyanthi, 2015). Persen inhibisi yang diperoleh dari pengujian digunakan untuk menghitung nilai IC50 yang merupakan parameter utama aktivitas antioksidan (Hardiyanthi, 2015).

Besarnya aktivitas antioksidan ditandai dengan nilai IC50, yaitu konsentrasi larutan sampel yang dibutuhkan untuk menghambat $50 \%$ radikal bebas DPPH (Andayani, dkk., 2008). Uji aktivitas antioksidan menggunakan metode DPPH terhadap 
$\mathrm{H} \& \mathrm{~B}$ lotion sari buah tomat pada formula II diperoleh IC50 sebesar $6,530 \mu \mathrm{g} / \mathrm{mL}$ lebih besar dari formula I dan formula II. Nilai IC50 yang paling kecil yaitu dihasilkan formula III dengan nilai sebesar 5,106 $\mu \mathrm{g} / \mathrm{mL}$. Nilai IC50 yang semakin kecil berarti semakin kuat daya antioksidannya (Rohman dan Riyanto, 2005).

Hasil analisis statistik menunjukkan bahwa data nilai IC50 terdistribusi normal, pada formula I nilai signifikasinya $0,956(p>0,05)$, formula II nilai signifikasinya $0,826(p>0,05)$ dan formula III nilai signifikasinya 0,780 $(p>0,05)$. Data nilai IC50 dari ketiga formula terdistribusi secara homogen dengan nilai signifikasinya 0,787 ( $p$ > 0,05). Hasil analisis statistik IC50 sediaan $\mathrm{H}$ \& $\mathrm{B}$ lotion sari buah tomat menunjukkan data terdistribusi secara normal dan homogen, sehingga dilanjutkan dengan uji Anova. Berdasarkan uji Anova, nilai IC50 sediaan $\mathrm{H} \& \mathrm{~B}$ lotion sari buah tomat dengan perbedaan konsentrasi sari buah tomat menunjukkan adanya perbedaan yang bermakna ( $p=0,001<$ $0,05)$. Analisis statistik selanjutnya dengan post hoc Bonferroniuntuk mengetahui adanya perbedaan antar formula. Uji post hocdidapatkan hasil bahwa antar formula I, II dan III nilai signifikansinya yaitu $0,001<0,05$ yang berarti terdapat perbedaan yang bermakna pada tiap formula. Berdasarkan analisis statistik konsentrasi sari buah tomat berpengaruh padaberpengaruh pada nilai IC50 sediaan H\&B Iotion sari buah tomat.

Berdasarkan hasil uji aktivitas antioksidan H\&B lotion sari buah tomat diketahui bahwa formula III memiliki daya antioksidan yang lebih kuat dibandingkan formula I dan II. Hal ini dikarenakan pada formula III mengandung konsentrasi sari buah tomat paling tinggi yaitu sebesar $50 \%$. Efek antioksidan yang dihasilkan terutama disebabkan karena adanya senyawa fenol seperti flavonoid dan asam fenolat. Pada umumnya senyawasenyawa yang memiliki aktivitas antioksidan adalah senyawa fenol yang mempunyai gugus hidroksi yang tersubstitusi pada posisi ortho dan para terhadap gugus $-\mathrm{OH}$ dan $-\mathrm{OR}$ (Andayani, dkk., 2008). Berdasarkan penelitian Andayani, dkk(2008) diketahui bahwa tomat mengandung fenolat dan flavonoid. Hasil penelitian tersebut kandungan fenolat total dalam ekstrak metanol buah tomat adalah $546,947 \mathrm{mg} / \mathrm{L}$ yang setara dengan $1859,46 \mathrm{mg} / \mathrm{kg}$ tomat segar dan kadar likopen adalah 14,725 $\pm 0,0017 \mathrm{mg} / \mathrm{kg}$ tomat segar.

\section{KESIMPULAN}

1. Konsentrasi sari buah tomat tidak berpengaruh pada karakteristik fisik sediaan H\&B lotion sari buah tomat meliputi organoleptis, homogenitas, $\mathrm{pH}$, daya proteksi, daya sebar, daya lekat dan tipe emulsi

2. Hasil uji stabilitas mekanik H\&B lotion sari buah tomat pada semua formula mengalami pemisahan fase

3. Hand \& Bodylotion sari buah tomat mempunyai aktivitas antioksidan dengan nilai IC50 pada formula I sebesar $5,697 \mu \mathrm{g} / \mathrm{mL}$, formula II sebesar $6,530 \mu \mathrm{g} / \mathrm{mL}$, dan formula III sebesar $5,106 \mu \mathrm{g} / \mathrm{mL}$. 
UCAPAN TERIMA KASIH

Ucapan terima kasih kami sampaikan kepada Yayasan Bernardus yang telah membiayai penelitiani ini.

\section{DAFTAR PUSTAKA}

Allen, L.V., Popovich, N.G., Ansel, H.C., 2014, Ansel Bentuk Sediaan Farmasetis \& Sistem Penghantaran Obat, Edisi 9, Penerbit Buku Kedokteran EGC, Jakarta

Ansel H.C.,1989, Pengantar Bentuk Sediaan Farmasi, UI Press, Jakarta.

Barel, A.O., Paye, M., Maibach, H.I., 2001, Handbook of Cosmetic Science and Technology, Marcel Dekker, Inc., New York

Hardiyanthi, F., 2015, Pemanfaatan Aktivitas Antioksidan Ekstrak Daun Kelor (Moringa oleifera) dalam Sediaan Hand and Body Cream, Skripsi, Program Studi Kimia, Fakultas Sains dan Teknologi, Universitas Islam Negeri Syarif Hidayatullah Jakarta.

Imam, D., 2006, Pengaruh Pemberian Jus Buah Tomat (Lycopersicum esculentum Mill) terhadap Motilitas Spermatozoa Mencit Balb/c Jantan yang Diberi Paparan Asap Rokok, Artikel Ilmiah, Fakultas Kedokteran, Universitas Diponegoro Semarang

Maulida, D., dan Zulkarnaen, N., 2010, Ekstraksi Antioksidan (Likopen) dari Buah Tomat dengan Menggunakan Solven Campuran, n-Heksana, Aseton, dan Etanol, Skripsi, Jurusan Teknik Kimia
Fakultas Teknik Universitas Diponegoro, Semarang.

Mu'nisa, A., 2012., Analisis Kadar Likopen dan Uji Aktivitas Antioksidan pada Tomat Asal Sulawesi Selatan, Jurnal Bionature, Volume 13, Nomor 1, hlm.62-66

Rohman, A., dan Riyanto S., 2005, Daya Antioksidan Ekstrak Etanol Daun Kemuning (Murraya paniculata (L) Jack) secara In Vitro, Majalah Farmasi Indonesia, Vol. 16, No. 3, halaman 136-140

Setiawati, E., Khaira, Fith N., \& Elfiyani R., 2014, Pengaruh Peningkatan Konsentrasi Setil Alkohol sebagai Pengental terhadap Stabilitas Fisik Krim Tipe M/A Ekstrak Rimpang Jahe Gajah (Zingiber Officinale Roscoe), Universitas Muhammadiyah Prof. dr. Hamka, Jakarta.

Standar Nasional Indonesia 16-43991996, Sediaan Tabir Surya, Badan Standarisasi Nasional, Jakarta.

Sulaiman, T.N., \& Kuswahyuning, R., 2008, Teknologi dan Formulasi Sediaan Semipadat, Laboratorium Teknologi Farmasi, Fakultas Farmasi Universitas Gadjah Mada, Yogyakarta.

Swastika,A., 2013. Aktivitas Antioksidan Krim Sari Buah Tomat. Vol 18, No.3 Hal 2. Fakultas Farmasi Universitas Gadjah Mada, Yogyakarta

Tsang, G., 2004, Can Likopen in Tomatoes Prevent Prostate Cancer?, http://www.healthcastle.com/likop en-prostatecancer.shtml, diakses tanggal 20 Juni 2018. 
Voigt, 1995, Buku Pelajaran Teknologi Farmasi, Gadjah Mada University Press, Yogyakarta.

Winata, H., 2011, Aktivitas Antioksidan dan Kandungan Kimiawi Ekstrak Daun Wungu (Graptophyllum pictum L.Griff.) http://repository.ipb.ac.id/jspui/bits tream/123456789/48301/11/G11h wi.pdf diakses tanggal 22 Juni 2018.

Zuhra, C.F., Tarigan, J.B., dan Sihotang, H., 2008, Aktivitas AntioksidanSenyawa Flavonoid Dari Daun Katuk(Sauropus androgunus (L) Merr.), Jurnal Biologi Sumatera, Vol. 3, No. 1, hlm. 7 - 10 